DOI: $10.17951 / \operatorname{lrp} .2020 .40 .1 .25-40$

\title{
Aleksander Piecuch
}

Uniwersytet Rzeszowski

ORCID - 0000-0001-5889-9643

\section{ZDEZORIENTOWANA DYDAKTYKA WSPÓŁCZESNYCH CZASÓW}

\begin{abstract}
Streszczenie: Współczesna dydaktyka stanęła na rozdrożu. Z jednej strony usiłuje zapobiec obniżającemu się poziomowi kształcenia na wszystkich szczeblach edukacji. Z drugiej poszukuje możliwości dostosowania się do współczesności i oczekiwań społecznych. Antidotum na problemy edukacyjne młodego pokolenia miała stać się powszechna informatyzacja szkół. W założeniach wykorzystanie środków informatycznych na zajęciach ma wpłynąć na poprawę jakości kształcenia, unowocześnić i uatrakcyjnić proces edukacyjny, wykorzystując przy tym naturalną fascynację młodego pokolenia nowymi technologiami. W ślad za powszechną informatyzacją uruchamiano szereg projektów o zasięgu lokalnym i ogólnokrajowym (np. Cyfrowa szkoła) bazujących na środkach informatycznych. Z krajowych i zagranicznych wyników badań efektywności kształcenia wspomaganego środkami informatycznymi jednoznacznie wynika brak skuteczności przyjętych rozwiązań. Synchronicznie do podejmowanych w szkołach działań praktycznych pojawiły się też nowe koncepcje: kognitywizm i konektywizm. Miały one spowodować zmiany w podejściu do procesów uczenia się i nauczania, by ostatecznie pozytywnie wpłynąć na efektywność kształcenia. Czy istotnie są one w stanie zmienić obraz edukacji na ten oczekiwany, czy też utrwalają istniejący stan rzeczy? Wobec wielu pojawiających się wątpliwości uprawnione jest stawianie pytań: o kierunki dalszego rozwoju metodyki wspomaganej środkami informatycznymi, o wpływ nowych koncepcji na jakość kształcenia. W niniejszym opracowaniu podejmuję próbę polemiki ze wspomnianymi problemami.
\end{abstract}

Słowa kluczowe: dydaktyka, kognitywizm, konektywizm

\section{WPROWADZENIE}

Powszechna informatyzacja objęła swoim zasięgiem wszystkie dziedziny ludzkiej działalności, w tym także edukację. Nie bez powodu już w ostatnich dekadach XX wieku pedagodzy zaczęli upatrywać w komputerach nowego uniwersalnego 
środka dydaktycznego. Powstawało wiele programów komputerowych, których celem było wspomaganie nauczania określonych treści kształcenia w obszarze różnych przedmiotów szkolnych. Równolegle zaczęły powstawać różnego rodzaju koncepcje i projekty mające na celu coraz szersze włączanie do nauczania środków informatycznych. Entuzjazm, jaki towarzyszył i wciąż towarzyszy zwolennikom nowego modelu nauczania $\mathrm{z}$ wykorzystaniem ICT (Technologie Informacyjno-Komunikacyjne), wyprzedził namysł nad konsekwencjami jego stosowania.

\section{DYDAKTYKA WOBEC ICT}

Od wielu lat w opinii społecznej pojawiają się głosy o niedostosowaniu szkoły do współczesnych realiów. Dotyczy ona w równym stopniu wszystkich szczebli kształcenia, począwszy od szkoły podstawowej, na wyższych uczelniach kończąc. Trudno zaprzeczyć stwierdzeniu, że szkoła od dziesięcioleci bazuje na tych samych zasadach i formach organizacyjnych pracy z uczniem. Pewnym cyklom zmienności podlegają jedynie podstawy programowe poszczególnych przedmiotów szkolnych. Teoretycy i praktycy edukacji są zgodni co do konieczności przebudowy szkoły współczesnej. Jak twierdzi Czesław Plewka, „w obliczu takiego świata o błyskawicznie zmieniającej się wokół nas rzeczywistości warunkiem przetrwania jest podążanie za tempem tych przemian. To wyzwanie ma wymiar interdyscyplinarny, a jedną $\mathrm{z}$ istotnych dziedzin, która nie może od tego wyzwania uciekać jest edukacja. Jest to o tyle ważne - jak podkreśla wielu uczonych - że udział nowoczesnych rozwiązań w procesie nauczania - uczenia się ma znamienny wpływ na kształtowanie się naszych zdolności adaptacyjnych tak ważnych w warunkach współczesnej rzeczywistości. Stąd w dobie powszechnej cyfryzacji techno edukacja powinna być naturalnym zabiegiem edukacyjnym stosowanym na każdym etapie procesu nauczania - uczenia się" (Plewka, 2017, s. 24-25).

Od początku istnienia szkół ich rolą było przygotowanie uczącego się pokolenia do życia i pracy w społeczeństwie lub, ujmując rzecz bardziej ogólnie, do sprawnego funkcjonowania w społeczeństwie. Wspomniane założenia są i będą aktualne. Ich urzeczywistnienie będzie możliwe tylko wówczas, kiedy szkoła wykaże się skutecznością swoich oddziaływań w sferze kształtowania określonych postaw, umiejętności i wiedzy uczących się. Tymczasem rzeczywistość okazuje się bardziej złożona. Współczesna szkoła pracuje pod presją: nowoczesności, instytucji zarządzających, rodziców i uczniów. W założeniach wszystkim chodzi o jej efektywne działanie, ale w rzeczywistości szkoła, chcąc zaspokoić zewsząd płynące postulaty, popada w coraz większy bezład organizacyjny. Do świadomości społecznej z trudem dociera, że szkoła jest specyficznym, ale jednak zakładem 
pracy dla pracujących w niej nauczycieli, jak również uczniów. Jeśli za modelowe przyjąć rozwiązania z typowego zakładu pracy, to na czele stoi dyrektor (dyrektor szkoły). Podlegają mu kierownicy działów (nauczyciele). Ci z kolei zarządzają pracownikami (uczniowie). Mamy zatem ściśle określoną hierarchię, według której powinna również pracować szkoła. Tymczasem to szkoła usilnie stara się dostosować do ucznia i oczekiwań rodziców. Skutkiem tego próba wyegzekwowania od podmiotu edukacji określonego zestawu kompetencji, staje się trudna, a czasem niemożliwa, bo ten czyni wszystko, by zrobić to przy minimalnym nakładzie pracy własnej. Dodając do tego masowość zjawiska w skali klasy/szkoły, „w rezultacie poziom wymagań sukcesywnie się obniża ze względu na rosnącą liczbę uczniów niemieszczących się w pierwotnie przyjętych założeniach" (Piecuch, 2019, s. 157).

Presja nowoczesności edukacji aktualnie sprowadza się do jej ucyfrowienia. Jak to wymownie określa literatura przedmiotu, dzięki ICT lekcje stają się atrakcyjniejsze i przyjemniejsze. Nie można odmówić racji autorom takich konkluzji. $\mathrm{Z}$ całą pewnością lekcje z ICT są atrakcyjniejsze, ale jak pokazują światowe i krajowe (np. Cyfrowa szkoła) wyniki badań, wcale nie są efektywniejsze. Potwierdza to Bronisław Siemieniecki, podając przykład szkół angielskich, kiedy w latach 80. XX wieku wprowadzono na szeroką skalę komputery do szkól. „Wówczas powszechnie funkcjonowało przekonanie, że wystarczy wprowadzić komputery i odpowiednie oprogramowanie do szkół, a efekty kształcenia pojawią się po czasie. Po kilku latach okazało się, jak błędne było to założenie. Nie tylko nie osiągnięto oczekiwanego wzrostu, ale okazało się, że wyniki kształcenia są niższe niż w okresie sprzed wprowadzenia komputerów do szkół” (Siemieniecki, 2013, s. 159). Już w 2002 roku Ryszard Pachociński przewidywał, że „technologia nie jest w stanie przyczynić się do zmian w nauczaniu i uczeniu się, ponieważ skuteczne procesy uczenia się następują w kontekście społeczno-kulturowym. Technologia może korzystnie wpływać na wyniki uczenia się tylko wtedy, gdy zostanie wykorzystana do realizacji ściśle ustalonych celów w szkole. Sprawą podstawową jest więc zadbać, by technologia została zintegrowana $\mathrm{z}$ kontekstem szkolnym, a zwłaszcza ze złożonym procesem zmian w szkole" (Pachociński, 2002, s. 109). Z dotychczasowych doświadczeń wynika konieczność spojrzenia na ICT w kategoriach wspomagających, a nie zastępujących tradycyjny proces kształcenia. „Konkludując: współczesna technologia informacyjna jest wielkim sprzymierzeńcem oświaty dzięki jej ogólnemu udostępnieniu i walce z obszarami wykluczenia, ale równocześnie może wykreować populację pozbawioną «analogowych» zmysłów, wiedzy i umiejętności. Jest tylko złożonym narzędziem, którego obsługi i rozumnego wykorzystania musimy się jeszcze z całą pewnością nauczyć” (Baron-Polańczyk, 2011, s. 117). „Powierzchowne obcowanie z informacją (treściami kształcenia) realizowane $\mathrm{z}$ wykorzystaniem technologii informacyjnych w rzeczywistości nie 
prowadzą do przyrostu wiedzy, bo ta zgodnie z propozycją B.C. Brookes’a (1) może mieć miejsce wówczas, gdy opiera się na ugruntowanej wiedzy:

$$
\Delta \mathrm{I}+\mathrm{W} \rightarrow \mathrm{W}+\Delta \mathrm{W}
$$

gdzie:

$\Delta \mathrm{I}$ - nowa informacja,

$\mathrm{W}$ - dotychczasowa wiedza,

$\Delta \mathrm{W}$ - przyrost wiedzy, jaki następuje dzięki informacji I” (Piecuch, 2014a, s. 343).

Trudne do zrozumienia i zaakceptowania są poglądy zmierzające do zastąpienia podręczników, a nawet zeszytów szkolnych środkami elektronicznymi. Czym różni się czytanie z książki od czytania z ekranu laptopa lub smartfonu? Odpowiedź jest bardzo krótka i jednoznaczna - różni się znacząco. W swoim opracowaniu monograficznym Studia nad czytelnością druku Bror Zachrisson konkluduje: „w czynności czytania jest zawartych wiele bodźców: treść, wygląd zewnętrzny czytanego tekstu, wpływ otoczenia i inne. Czytelność nigdy nie zależy wyłącznie od tekstu: zawsze należy uwzględnić funkcjonalną sytuację czytelnik - tekst" (Zachrisson, 1970, s. 33-34). Z powyższego wynika, że o czytaniu ze zrozumieniem nie decydują wyłącznie procesy recepcyjne, ale także szereg innych czynników. Materiał drukowany ma określoną formę (skład) tekstu, format, wagę, grubość. Wszystkie te elementy w pośredni sposób decydują o sprawnym nawigowaniu po tekście. Stosunkowo łatwo zlokalizować przeczytany uprzednio tekst. Potrafimy skojarzyć, że był to np. ostatni akapit u dołu prawej strony książki mniej więcej w połowie jej objętości. Takie skojarzenia nie będą miały miejsca w przypadku urządzeń elektronicznych (laptop, tablet, czytnik e-booków). Użycie do tych samych celów narzędzi wyszukiwania, o ile jest to możliwe, nie jest rozwiązaniem efektywnym, ponieważ na ogół pamiętamy kontekst, a nie dosłowne sformułowania. Czytający nie jest w stanie określić położenia, w którym miejscu książki aktualnie się znajduje. Nie może także w łatwy sposób porównać tekstu aktualnie czytanego z fragmentem, który znajduje się np. kilkanaście stron wcześniej czy później. Konieczność przewijania ekranów gubi orientację czytelnika i sprawia, że ten zaczyna własną uwagę skupiać na nawigacji, a nie na czytanym tekście. Efektem tego jest niższa zdolność zapamiętywania (Piecuch, 2014b). Liczne badania naukowe wykonane na uniwersytetach: „Stavanger (Norwegia), Karlstads (Szwecja), Central Florida (USA), San Jose State (USA), Technion - Israel Institute of Technology (Izrael), National Taiwan University, Universidad Nacional Autónoma de México dowodzą zwiększonej skuteczności uczenia się z wykorzystaniem tekstów dostępnych w formie tradycyjnej - drukowanej niż elektronicznej. Jeśli nawet teksty posiadały tylko formę elektroniczną, to i tak były drukowane przez użytkowników" (Jabr, 2013, s. 
63). Sprawność pracy z tekstem to tylko jeden z wycinków problemu. Sięgając po urządzenia ekranowe, nie można pominąć aspektów natury medycznej. Według Journal of Applied Physiology ekrany LED zakłócają rytm sen - czuwanie. Niebieskie światło o długości fali $464 \mathrm{~nm}$, jakie emitują także ekrany LED, nie pozwala zasnąć (Pająk, 2013), ale także przyczynia się do powstania zmian zwyrodnieniowych siatkówki oraz powoduje rozwój AMD, czyli zwyrodnienia plamki żółtej (http:// www.echirurgia.pl/, 2018). Inicjatywy zmierzające do intensyfikacji wykorzystania ICT w edukacji w praktyce zmierzają do wypchnięcia szkoły z jej naturalnego kulturotwórczego środowiska w bliżej nieokreśloną kulturowo wirtualną przestrzeń.

„Eksponowany w literaturze przedmiotu wykładniczy przyrost wiedzy, której szkoła nie będzie w stanie przekazać, a za którym nie sposób nadążyć bez udziału ICT, w rzeczywistości odnosi się do nauki przez duże «N», natomiast w realiach szkolnych nie jest ona udziałem uczniów" (Piecuch, 2016, s. 112). Istotnie XX i XXI wiek w historii rozwoju cywilizacyjnego zapisze się złotymi zgłoskami, jako czas dynamicznego rozwoju nauki i techniki. Coraz nowocześniejsze i doskonalsze instrumenty badawcze pozwalają badaczom przesuwać granice poznania naukowego. Dzięki temu wiemy i rozumiemy coraz więcej. Nie zmienia to jednak faktu, że w kilku ostatnich dziesięcioleciach nauka nie dokonała odkryć na miarę Kopernika, Newtona i innych, a które zmieniłyby pogląd na znane i nauczane dotąd w szkole teorie naukowe. Nie zaszły więc zasadnicze zmiany w treściach merytorycznych, natomiast jest ich zdecydowanie mniej niż w programach nauczania sprzed kilkudziesięciu lat. Wyraziście widać to na przykładzie matematyki. Najprostszym, najszybszym i najbardziej miarodajnym porównaniem będzie sięgnięcie do licealnych podręczników matematyki z lat 80. minionego stulecia i obecnych. To dziś uczelnie wyższe, szczególnie techniczne, pierwszy rok studiów poświęcają tym treściom kształcenia, które niegdyś znajdowały się w programach szkoły średniej.

Wśród wielu entuzjastów ICT istnieje przekonanie, że jest to droga do wyrównywania szans edukacyjnych. Obawiam się, że jest odwrotnie - to pogłębianie dysproporcji w edukacji. Będąc dalekim od uogólniania zjawisk społecznych w środowisku młodego pokolenia, musimy uznać, że dla jego pewnej części, myślącej odpowiedzialnie w kategoriach własnej przyszłości jest to droga do samorozwoju, dla pozostałej części kierującej się odmienną hierarchią już taką drogą nie będzie. Posłużmy się przykładem czytelnictwa. W dniu 5. grudnia 2017 roku został uruchomiony portal lektury-gov-pl. Liczby wyświetleń strony kształtowały się na poziomie (https://widok.gov.pl/, 6.12.2020):

- w roku otwarcia portalu (grudzień 2017) - 35364 odsłon,

- w 2018 roku - 8993,

- w 2019 roku - 17 639,

- w 2020 roku - brak danych. 
Z przywołanych danych statystycznych wynika, że moment uruchomienia portalu był jednocześnie momentem kulminacyjnym dla portalu. W kolejnych latach liczba odsłon nie sięgnęła już takiego poziomu zainteresowania. Z punktu widzenia prowadzonej analizy można żałować braku danych statystycznych za 2020 rok, w którym z powodu pandemii szkoły, a wraz z nimi szkolne biblioteki, przestały funkcjonować w normalnym trybie. Porównanie czytelnictwa okresu społecznej izolacji z latami poprzedzającymi pandemię rzuciłoby nowe światło na stopień zainteresowania czytelnictwem (a może szerzej także edukacją) współczesnych uczniów.

\section{KONCEPCJA KOGNITYWIZMU}

Termin „kognitywistyka” pojawia się stosunkowo często w różnych opracowaniach (tytułach) odnoszących się do edukacji. Nie zawsze są to odwołania poprawne i uprawnione. Sięgnijmy zatem do autorytetów. Profesor Włodzisław Duch objaśnia: „[...] w wyniku integracji wielu różnych gałęzi nauki pojawiła się realna perspektywa zrozumienia umysłu. Tę grupę nauk nazwano «naukami o poznaniu» (ang. cognitive sciences), lub naukami kognitywnymi, od łacińskiego słowa cognitio, czyli wiedza. Rdzeń «kognicja» obecny jest w używanym w języku polskim słowie "prekognicja», pochodzącym od łacińskiego słowa oznaczającego «wiedzieć wcześniej». Chociaż w skład nauk kognitywnych wchodzi wiele tradycyjnych gałęzi nauki, to powoli wyłania się z nich wspólny obszar badań, któremu warto jest nadać odrębną nazwę. Jak powiedział jeden $\mathrm{z}$ twórców tej dziedziny, Allen Newell, nowe gałęzie nauk nie powstają dlatego, że ktoś postanowił je zdefiniować, a raczej dlatego że pewna grupa ludzi dostrzega, iż mają wspólny temat do dyskusji, powstają pisma, stowarzyszenia, zwołuje się konferencje. Ściśle rzecz ujmując, nazwę «kognitywistyka» należałoby zarezerwować tylko dla tych prac prowadzonych w ramach nauk kognitywnych, które zajmują się tworzeniem modeli umysłu. W praktyce używana jest ona zamiennie z nazwami «nauki o poznawaniu» czy «nauki kognitywne»" (Duch, 1998, s. 10-11).

Na podbudowie kognitywistyki próbuje osadzić się inna dyscyplina - neurodydaktyka. „W świetle literatury neurodydaktyka jest nową, interdyscyplinarną dziedziną badawczą zajmującą się mechanizmami uczenia się i nauczania, korzystającą $\mathrm{z}$ dorobku takich nauk jak: dydaktyka, neurobiologia, psychologia poznawcza, teoria sieci neuronowych" (Piecuch, 2008, s. 280). Termin ten został użyty po raz pierwszy w pracy prof. Gerharda Preisa w 1992 roku. Preis próbuje weryfikować wyniki symulacji komputerowych uczenia sieci neuronowych [...]. Jednym z zadań badawczych neurodydaktyki jest poszukiwanie prawidłowości 
procesu uczenia się i nauczania inspirowane wynikami neurobiologii, psychologii poznawczej, teorii sieci neuronowych (Błasiak, 1996. s. 30).

Z poprawnością nazwy „neurodydaktyka” polemizuje Anna Karcz-Czajkowska: „[...] jest dość powszechna w świecie nauki moda na nadawanie przedrostka neuro coraz to nowym obszarom wiedzy - często bez solidnego uzasadnienia ich wkładu w dyscyplinę podstawową, którą w tym wypadku stanowi neurobiologia. Oczywiście jest to całkowicie uzasadnione w przypadku badań czy rozważań teoretycznych, które faktycznie zwiększają ogólną pulę wiedzy w zakresie obu dyscyplin składowych - jak obserwujemy w przypadku neuropsychologii, która nieustannie przyczynia się do rozwoju nauki zarówno o funkcjonowaniu mózgu, jak i o procesach mentalnych. Jednak gdy nowopowstała dziedzina nie wnosi nic nowego do istniejącej już wiedzy o mózgu, czerpiąc z niej jedynie informacje użyteczne w praktycznym działaniu, zastosowanie przedrostka neuro wydaje się nieuzasadnionym zabiegiem, nie wykraczającym poza sferę nomenklatury" (Karcz-Czajkowska, 2014, s. 207).

Jeśli analitycznie potraktować cytowane wypowiedzi Ducha i Karcz-Czajkowskiej, musimy przyznać, że istotnie neurodydaktyka nie dysponuje żadnym wkładem naukowym w wiedzę o mózgu. Opiera się jedynie na faktach dawno potwierdzonych naukowo i na tej podstawie uzasadnia działania dydaktyczne. Funkcje półkul mózgowych z podziałem na lewą i prawą są znane od dawna i bez trudu można je odszukać w dostępnej literaturze. Już w 1998 roku Wincenty Okoń w czwartym wydaniu swojej książki Wprowadzenie do dydaktyki ogólnej pisał: „Funkcje obu półkul nie mogą funkcjonować niezależnie od siebie, a tym samym, że nie jest możliwe stosowanie względem nich odrębnych, wyizolowanych sposobów oddziaływania pedagogicznego. Toteż może nas uspokoić stwierdzony przez neurologów fakt komplementarnego charakteru ich funkcji. [...] Harmonijna interakcja obu półkul mózgowych jest warunkiem pełnego rozwoju człowieka. Wymaga ona jednak wielostronnego pobudzania ośrodków, zlokalizowanych zarówno w lewej, jak i prawej półkuli mózgu" (Okoń, 1998, s. 193-194). Dla praktyki pedagogicznej może to oznaczać tylko jedno - realizację teorii kształcenia wielostronnego poprzez szerokie i zróżnicowane spektrum oddziaływań pedagogicznych na podmiot edukacji. Przypomnijmy, że chodzi tu o trzy komponenty: „aktywność intelektualną, dalej aktywność o charakterze emocjonalnym, dotyczącą stosunku człowieka do wartości i wreszcie aktywność praktyczną, która polega na jego osobistym udziale w przekształcaniu rzeczywistości, głównie w procesie pracy wytwarzającej nowe wartości” (Okoń, 1998, s. 196).

W ostatnich dwóch dekadach medycyna poczyniła bardzo duże postępy m.in. w metodach obrazowania medycznego. Doczekała się instrumentów technicznych, które pozwalają zobaczyć i zarejestrować aktywność mózgu człowieka, czy też 
„mierzyć stopień aktywacji w określonych, jasno zdefiniowanych warunkach” (Spitzer, 2007, s. 114). „Dzięki diagnostyce obrazowej możemy uwidocznić wielkość i aktywność całych obszarów mózgu i tym samym w imponujący sposób wykazać skutki uczenia się na płaszczyźnie neuronalnej” (Spitzer, 2015, s. 17). Przywołane cytaty z publikacji Manfreda Spitzera potwierdzają słowa Okonia. Uprawnione jest zatem postawienie pytania: co w praktyce współczesnemu nauczycielowi daje wiedza o funkcjonowaniu mózgu? Na pewno większą świadomość własnych działań pedagogicznych w pracy z uczniami, ale poza tym chyba niewiele więcej wynika $z$ tej wiedzy dla praktyki pedagogicznej. Zidentyfikowane funkcje półkul mózgowych, takich jak: mowa, analiza, myślenie abstrakcyjne, synteza, kojarzenie, kreatywność itd., w praktyce są w każdym przypadku rozwijane od niemowlęctwa, a następnie wzmacniane i rozwijane zarówno w toku codziennego życia, jak i szkolnej edukacji.

Poruszając się na pograniczu obszarów kognitywistyki i edukacji wspomaganej środkami informatycznymi, warto kilka słów poświęcić propozycji Marca Prensky’ego podziału użytkowników ICT. Wyróżnia on dwie grupy użytkowników: 1) cyfrowych tubylców (ang. digital natives), 2) cyfrowych imigrantów (ang. digital immigrants) (Prensky, 2001). Autor przytoczonego podziału twierdzi, że skoro mózg cechuje neuroplastyczność, to w wyniku obcowania młodego pokolenia $\mathrm{z}$ ICT prowadzi to do zmian zachodzących w mózgach użytkowników. W świetle wiedzy, którą na dzień dzisiejszy posiadamy o mózgu, uprawnione jest pytanie: czy proponowany podział ma uzasadnienie? Jeśli potraktować ów podział w kategoriach: urodzony przed rokiem..., urodzony po roku... - to można uznać go za uzasadniony, chociaż warto przypomnieć, że w literaturze funkcjonuje analogiczny podział na pokolenie: X, Y, Z. Literatura z zakresu neurobiologii nie dostarczyła jak do tej pory żadnych dowodów na to, że istnieją jakiekolwiek różnice pomiędzy pokoleniem uważanym przez Prensky'ego za imigrantów a pokoleniem tubylców. Badania przeprowadzone przez Gary’ego Small i Gigi Vorgan (2011) z wykorzystaniem metody obrazowego badania aktywności mózgu przy zastosowaniu rezonansu magnetycznego (fMRI) potwierdzają niezwykłą plastyczność mózgu. Porównanie grupy kontrolnej (użytkowników ICT) i starszego pokolenia - niekorzystających z ICT, wykazuje jedynie różnice w aktywowaniu się różnych obszarów mózgu. Jednakże już po pięciogodzinnym treningu u starszego pokolenia aktywują się te same obszary mózgu co w grupie kontrolnej. Nie ma zatem żadnego naukowego dowodu, a tym samym powodu, by dzielić użytkowników ICT na tubylców i imigrantów. Zatem z naukowego punktu widzenia taki podział nie ma sensu. Faktem jest, że wiek niesie ze sobą pewne ograniczenia. Na przykład niektóre czynności, jak sprawność pisania na klawiaturze, mogą być wykonywane wolniej. W niczym nie zmienia to istoty problemu, że nauka także bez tych bardzo 
zaawansowanych technologii jest możliwa, w każdym wieku i pozostaje funkcją odpowiednio dobranego merytorycznie i czasowo treningu. Zwróćmy uwagę, że za kilka/kilkanaście lat pokolenie dzisiejszych tzw. imigrantów odejdzie. Pozostaną pokolenia „tubylców”, wśród których i tak znajdą się niekorzystający z komputerów.

Literatura przedmiotu, jak na razie, nie dostarcza dowodów na to, aby neurobiologia była w stanie zaproponować pedagogom konkretne rozwiązania poprawiające w istotny sposób efektywność kształcenia. Niemniej jednak pewne wnioski można formułować. Znamy już i potrafimy określić czynniki, które sprzyjają, a które ograniczają procesy uczenia się. Natomiast wpływ na to, jak przetwarzane i przechowywane są informacje w naszym mózgu (mózgach uczniów), mamy mniej więcej taki sam, jak na zapis informacji w określonym sektorze dysku twardego komputera.

\section{KONCEPCJA KONEKTYWIZMU}

Analogiczne obiekcje budzi eksponowana w literaturze odmienność ról nauczyciela i utrata jego znaczenia w procesie edukacyjnym. „Nauczyciel w epoce cyfrowej nie jest ekspertem od wiedzy, ale specjalistą od organizacji uczenia się” (Wróblewska, 2014, s. 202). Sądzę że, im bardziej będzie rósł niekontrolowany sposób wykorzystania Sieci przez młodzież szkolną do celów edukacyjnych, tym bardziej będzie potrzebna interwencja nauczyciela. Dostęp do określonych zasobów internetowych jest możliwy do ograniczenia tylko na terenie szkoły, ale nie można go ograniczyć poza jej terenem. Przy tak dużym przeładowaniu informacyjnym uczeń „najczęściej nie dysponuje odpowiednimi kompetencjami, nie posiada narzędzi i nie zna metod, które pozwoliłyby jej szybko przekształcić nadmiernie dużą ilość informacji w wiedzę usprawniającą jego działanie" (Furmanek, 2014, s. 15), a założyć trzeba, że informacje, z którymi potencjalnie zetknie się w Sieci, mogą być nieprawdziwe, częściowo zafałszowane lub niepełne, a jak zauważa Włodzimierz Gogołek zaufanie do Sieci „bezkrytycyzm przyjmowania treści z Sieci «to czego nie ma w Googlach, nie istnieje». W efekcie kreowana jest prosta ścieżka do manipulacji młodymi internautami” (Gogołek, 2015, s. 109). Wobec tego stajemy przed problemem syndromu niepewności informacji, a w następstwie tego syndromu niepewności wiedzy. Któż zatem, jeśli nie nauczyciel, może być tym, który kompetentnie będzie orzekał o wiarygodności informacji. „Przyjmując takie założenie w rzeczywistości nie zmierzamy do poprawy jakości kształcenia ani zwiększenia jej efektywności, jeśli nauczyciel będzie musiał częściej niż zwykle korygować uczniowskie błędy" (Piecuch, 2016, s. 111). To wymierna strata czasu, który można efektywniej wykorzystać na pracę z uczniem. 
Nowy nurt konektywizmu w edukacji pojawił się w 2005 roku za sprawą Georga Siemensa i Stephena Downesa i zakłada, że: „nie wszystko musimy mieć w głowie. Wiedza, którą posiadamy wcale nie musi być w nas, może znajdować się w zasobach poza nami (np. w zorganizowanych zasobach czy bazach danych) i to dopiero połączenie się z tymi zasobami czy bazami uruchamia proces uczenia się. Sama czynność łączenia się (w celu edukacyjnym) staje się ważniejsza niż to, co aktualnie wiemy. [...] Inaczej mówiąc «wiedzieć jak» (know-how) czy «wiedzieć co» (know-what) zostaje zastąpione przez «wiedzieć gdzie» (know-where), ponieważ to jest klucz prowadzący do poszukiwanego zasobu wiedzy. Staje się on meta-zasadą efektywnego uczenia się, równie ważną jak zasoby wiedzy, którą już posiadamy" (Polak, 2018). W myśl zasad konektywizmu uczenie się teraźniejsze i konektywne przybierze postać, jaką pokazano w tabeli 1.

Tabela 1.

Uczenie się tradycyjne a konektywne (źródło: Sławiński, 2018)

\begin{tabular}{|c|c|}
\hline Uczenie się tradycyjne, dzisiejsze & Konektywne uczenie się - w szkole jutra \\
\hline Zapamiętywanie faktów, dat, szczegółów... & Łączenie się z zasobami informacji \\
\hline Rozumienie procesów i zjawisk & Gromadzenie wiedzy w urządzeniach \\
\hline Kształcenie pojęć & Odnajdywanie (poszukiwanie) wiedzy \\
\hline Ćwiczenie umiejętności & Tworzenie i utrzymywanie połączeń \\
\hline $\begin{array}{c}\text { Rozwiązywanie różnych zadań przedmiotowych } \\
\text { teoretycznych i praktycznych }\end{array}$ & $\begin{array}{c}\text { Spostrzeganie związków między obszarami, ideami } \\
\text { i koncepcjami }\end{array}$ \\
\hline Nabywanie osobistych doświadczeń & Krytyczne myślenie \\
\hline Rozwiązywanie przykładowych testów & $\begin{array}{c}\text { Wybieranie treści uczenia się i samodzielne podej- } \\
\text { mowanie decyzji }\end{array}$ \\
\hline
\end{tabular}

Za komentarz do zestawienia tabelarycznego niech posłuży wypowiedź: „Bezsensowne stało się uczenie się faktów, wielu terminów, nazwisk i dat. Po prostu to straciło swój sens, kiedy takie informacje są łatwo dostępne po naciśnięciu klawisza komputera" (Sławiński, 2018). Wypowiedź ta wskazuje więc, że zapamiętywanie (uczenie się) czegokolwiek nie ma sensu bo wszystko można pozyskać natychmiast z Sieci po naciśnięciu klawisza. Podążając tym tokiem myślenia, można dojść do wniosku, że szkoła jako instytucja też nie ma racji bytu - przecież wszystko jest w Internecie. Na marginesie dodajmy, że wiedzy nie można gromadzić (w sensie jej zapisu na nośnikach elektronicznych) ani odnajdywać w Sieci. Możemy gromadzić jedynie informacje. Wiedzę natomiast tworzy każdy indywidualnie we własnym umyśle według własnych zasad i form pracy z informacją. Wizja tak unowocześ- 
nionej edukacji otwierającej się na idee konektywizmu jest niebezpieczna z kilku powodów (Piecuch, 2019, s. 162-164):

- „Po pierwsze: dlatego, że wytwarza przeświadczenie o wiedzy funkcjonującej poza umysłem człowieka - co jest nieprawdą i manipulacją. «Wiedza jest tworzona przez umysły i nie istnieje poza umysłami. Książki i komputery nie zawierają wiedzy. [...] Dlaczego sądzimy, że encyklopedia leżąca na stole, podręcznik, fotografia, film lub baza internetowa zawiera wiedzę? Przecież to nieprawda, a nawet więcej - jawny absurd. [...] sądząc złudnie, że książki zawierają informację i wiedzę, podobnie jak płyty CD i dyski komputerów, pomijamy (implicite) inherentną rolę umysłów w procesie odczytywania, rozumienia i twórczego przekształcania wiedzy» (Nosal, 2011/2012, s. 77-79).

- Podrugie: to cicheprzyzwolenie na intelektualne lenistwo ikomfort bezmyślności.

- Po trzecie: to akceptacja dehumanizacji. Zdając się wyłącznie na informacje zgromadzone na serwerach sieciowych, czyli poza umysłem - tracimy orientację czasową, przestaniemy rozumieć własną historię i kulturę, a w konsekwencji samych siebie. Skupienie się na «tu i teraz» prowadzi do prostej zależności «nie wiemy, skąd przyszliśmy i dokąd zmierzamy».

- Po czwarte: konektywizm nie jest metodą nauczania, ale tylko metodą/ sposobem pozyskiwania informacji.

- Po piąte: nie istnieje (jak to zakłada konektywizm - uczenie się jest procesem łączenia się z określonymi węzłami lub zasobami informacji) żadne łączenie się z węzłami. «Uczenie się oznacza modyfikację synaptycznej siły przenoszenia impulsów. Taka modyfikacja odbywa się jedynie w synapsach, które są aktywne. Im bardziej aktywna jest tkanka nerwowa w określonym obszarze kory mózgowej, z tym większym prawdopodobieństwem dojdzie w niej do zmian siły połączeń synaptycznych i do uczenia się» (Spitzer, 2012, s. 114).

- Po szóste: z charakterystyki zasad konektywizmu wynika milczące, a zarazem błędne założenie, o prawdziwości i rzetelności wszystkich dostępnych informacji. «W Sieci każdy może umieścić materiały, które inni potraktują jako źródło informacji lub materiał do edukacji, a teksty amatorów mogą zostać pomylone z pracami fachowców. Tak więc wprowadzanie w błąd i manipulowanie może być równie powszechne, a nawet częstsze niż rzetelne informowanie» (Keen, 2007, s. 45).

- Po siódme: brak wartości dodanej. Wszystko zaczyna się w momencie próby dotarcia do informacji i kończy z chwilą jej odnalezienia.

- Po ósme: nie uruchamia procesów poznawczych, ale uczy mechanicznego przetwarzania informacji. Przecież ważniejsze niż «wiedzieć gdzie» jest informacja, a nie jaki jest jej ladunek intelektualny. 
- Po dziewiąte: uczenie się i wiedza nie opiera się na różnorodności opinii, to zastępowanie w Sieci autorytetu przez modę i głos większości - tzw. efekt społecznego dowodu słuszności (Wieczorkowska-Wierzbińska, 2011). Tylko fakty, prawa, zasady potwierdzone naukowo są podstawą do budowania rzetelnej wiedzy o świecie i prawach nim rządzących.

- Po dziesiąte: proces podejmowania decyzji sam w sobie jest już procesem uczenia się. Nie jest - brak decyzji też jest decyzją, a brak aktywności nie wnosi niczego do procesu uczenia się" (Piecuch, 2019, s. 162-164).

Podsumowując, w tabeli 2 dla celów porównawczych zestawiono pozytywne i negatywne skutki stosowania ICT w edukacji.

Tabela 2.

Pozytywne i negatywne skutki stosowania ICT w edukacji (źródło: Piecuch, 2019, s. 164-165, modyfikacja własna)

\begin{tabular}{|c|c|c|}
\hline Kategoria & Skutki pozytywne & Skutki negatywne \\
\hline Język & \multirow{2}{*}{$\begin{array}{c}\text { Biblioteki cyfrowe; do- } \\
\text { stęp online do słowników } \\
\text { i encyklopedii; powszechny } \\
\text { dostęp do duplikatów źródeł } \\
\text { drukowanych }\end{array}$} & $\begin{array}{c}\text { Zubożenie języka; kłopoty z ortografią, interpunkcją, } \\
\text { stylistyką; } \\
\text { kłopoty z werbalizacją }\end{array}$ \\
\hline Czytanie & & $\begin{array}{l}\text { Skanowanie tekstu wzrokiem; czytanie bez zrozu- } \\
\text { mienia }\end{array}$ \\
\hline Uczenie się & $\begin{array}{l}\text { Urozmaicone dzięki pre- } \\
\text { zentacji tych samych treści } \\
\text { w zróżnicowanej formie }\end{array}$ & $\begin{array}{c}\text { Uczenie się hipertekstowe; obniżona trwałość uwagi; } \\
\text { autorytet Sieci }\end{array}$ \\
\hline Uwaga & Podzielność uwagi & Rozpraszana przez Sieć \\
\hline Pamięć & - & $\begin{array}{c}\text { Pamięć Sieci (idee konektywizmu); kłopot z koncen- } \\
\text { tracją }\end{array}$ \\
\hline $\begin{array}{c}\text { Umiejętności } \\
\text { intelektualne - } \\
\text { poznawcze }\end{array}$ & Jest narzędziem poznawczym & $\begin{array}{l}\text { Niedobór informacji lub jej nadmiar; utrata zdolności } \\
\text { abstrakcyjnego myślenia i wyobraźni; wnioskowania } \\
\text { (logika formalna) }\end{array}$ \\
\hline Wiedza & $\begin{array}{c}\text { Szybkość wyszukiwania } \\
\text { informacji }\end{array}$ & $\begin{array}{c}\text { Powierzchowna, oparta głównie na streszczeniach; } \\
\text { brak umiejętności analizy i syntezy }\end{array}$ \\
\hline Kultura & Łatwość dotarcia & Kultura masowa mało ambitna \\
\hline Kreatywność & Gotowe rozwiązania & $\begin{array}{l}\text { Brak samodzielności; brak kreatywności - }(\mathrm{Ctrl}+\mathrm{C} ; \\
\text { Ctrl+V); działania odtwórcze }\end{array}$ \\
\hline $\begin{array}{l}\text { Aktywność } \\
\text { społeczna }\end{array}$ & $\begin{array}{l}\text { Sieci społecznościowe; } \\
\text { zawodowe fora dyskusyjne; } \\
\text { możliwość publikowania } \\
\text { w Sieci (Web 2.0); e-usługi }\end{array}$ & $\begin{array}{l}\text { Nasilenie się różnorodnych zagrożeń: alienacja, } \\
\text { przemoc i agresja, deprawacja; oszustwa internetowe; } \\
\text { stalking; netoholizm, hazard; cyberbullying; child } \\
\text { grooming; rasizm i ksenofobia; cyfrowe narkotyki; } \\
\text { handel np. środkami odurzającymi; publikacje o wąt- } \\
\text { pliwych walorach poznawczych, często obraźliwe }\end{array}$ \\
\hline $\begin{array}{l}\text { Relacje } \\
\text { interpersonalne }\end{array}$ & Natychmiastowe & $\begin{array}{c}\text { W coraz większym stopniu realizowane za pomocą } \\
\text { komunikatorów }\end{array}$ \\
\hline
\end{tabular}




\begin{tabular}{|c|c|c|}
\hline Kategoria & Skutki pozytywne & Skutki negatywne \\
\hline $\begin{array}{l}\text { Umiejętności } \\
\text { technologiczne }\end{array}$ & $\begin{array}{c}\text { Szybkość posługiwania się } \\
\text { klawiaturą i myszą; doskona- } \\
\text { lenie umiejętności percepcyj- } \\
\text { no-motorycznych }\end{array}$ & $\begin{array}{l}\text { Zanik umiejętności odręcznego pisania; niechęć do } \\
\text { pisania ręcznego }\end{array}$ \\
\hline $\begin{array}{l}\text { Zarządzanie } \\
\text { czasem }\end{array}$ & Szybki dostęp do informacji & $\begin{array}{l}\text { Brak refleksji nad rzetelnością informacji; } \\
\text { całkowita lub częściowa utrata czasu wolnego }\end{array}$ \\
\hline $\begin{array}{c}\text { Zdrowie } \\
\text { psychiczne }\end{array}$ & $\begin{array}{l}\text { Poczucie niezależności, } \\
\text { wolności }\end{array}$ & $\begin{array}{c}\text { Infostres; stres informacyjny; uzależnienie od Sieci, } \\
\text { urządzeń, treści i usług }\end{array}$ \\
\hline Zdrowie fizyczne & $\begin{array}{l}\text { Niski wydatek energetyczny } \\
\text { dla człowieka }\end{array}$ & $\begin{array}{l}\text { Dolegliwości narządu wzroku, dolegliwości układu } \\
\text { mięśniowo-szkieletowego; dolegliwości psychosoma- } \\
\text { tyczne }\end{array}$ \\
\hline
\end{tabular}

\section{PODSUMOWANIE}

Wizje unowocześniania szkoły przybierają różne postacie. Ciągłym zmianom ulegają podstawy programowe kształcenia ogólnego, z drugiej, a zarazem dominującej, strony to nasycanie szkół środkami informatycznymi. Oczywiście nie ma w tym nic złego, że szkoła jest dobrze wyposażona w nowoczesny sprzęt. Ilość jednak nie przechodzi w jakość, a hurtowe wykorzystywanie ICT w kształceniu, „bo takie są oczekiwania, bo tak trzeba", tylko pogłębia jej bezład. Od szkoły oczekuje się zmian, natomiast nie oczekuje się ich od postaw uczniów. Nawet najlepsza szkoła, z nauczycielami profesjonalistami nie nauczy niczego żadnego ucznia, jeśli ten nie będzie tego chciał, a nawet nie będzie odczuwał takiej potrzeby. Uczniowie przede wszystkim powinni być zmotywowani do uczenia się i osiągania jak najlepszych wyników - na miarę swoich możliwości. To zadanie nie tylko szkoły, ale także, a może przede wszystkim, rodziców. Bez względu na to, kto podejmie to wyzwanie, podstawą jest pokazanie młodemu człowiekowi celu, do którego powinien dążyć. Wskazanie celu to pokazanie możliwych perspektyw zawodowych i życiowych oraz wskazanie warunków koniecznych, które determinują jego osiągnięcie. Do tego potrzebna jest wytrwałość i odpowiedzialność każdej ze stron. Niestety „pokolenie Sieci jest słabo przygotowane na przyjęcie takiej odpowiedzialności współczesna szkoła bowiem raczej zdejmuje z ucznia wszelką odpowiedzialność, niźli ją kształtuje" (Morbitzer, 2011, s. 223).

Media cyfrowe nie są ani dobre, ani złe. Ich użytkownicy ze swoimi wyborami decydują o tym, czy okażą się dla nich dobre czy złe. Szkoła jako instytucja powinna tak kierować pracą uczniów, aby te wybory okazywały się dla nich jak najlepsze. Stosowanie ICT w procesie dydaktycznym musi znaleźć swoje umocowanie w merytorycznych i przede wszystkim metodycznych przesłankach. Presja 
nowoczesności taką przesłanką z pewnością nie jest. Uczmy więc kreatywności, innowacyjności i odpowiedzialności w rozsądny sposób, a ICT niech staną się narzędziem wspomagającym rozwój intelektualny.

\section{LITERATURA}

Baron-Polańczyk, E. (2011). Chmura czy silos? Nauczyciele wobec nowych trendów ICT. Zielona Góra: Wyd. UZ.

Błasiak, W. (1996). Marzenia o teorii nauczania. Perspektywy rozwoju dydaktyk przedmiotowych. Kraków: Impuls.

Duch, W. (1998). Czym jest kognitywistyka? Kognitywistyka i Media w Edukacji, 1, 10-11. Furmanek, W. (2014). Niektóre pedagogiczne konsekwencje nadmiarowości informacji. W: R. Wawer. M. Pakuła (red.). Technologie informacyjno-komunikacyjne w edukacji XXI wieku (s. 13-27). Lublin: Wyd. Lubelskie Towarzystwo Naukowe. Gogołek, W. (2015). (Nie)bezpieczny wymiar IT w edukacji. W: W. Czerski. R. Wawer (red.). Nowoczesne media w przestrzeniach edukacyjnych (s. 105-116). Lublin: Wyd. UMCS. GUS [Główny Urząd Statystyczny] (2019). Społeczeństwo informacyjne w Polsce. Wyniki badań statystycznych z lat 2015-2019. Warszawa - Szczecin: GUS. https://widok.gov.pl/statistics/lektury-gov-pl/ [dostęp: 6.12.2020].

Jabr, F. (2013). Papier kontra ekran. Świat Nauki, 12, 63.

Karcz-Czajkowska, A. (2014). Marzena Żylińska, Neurodydaktyka. Nauczanie i uczenie się przyjazne mózgowi (recenzja). Kwartalnik pedagogiczny, 4, 205-209.

Keen, A. (2007). Kult amatora. Jak internet niszczy kulturę. Warszawa: WAiP.

Morbitzer, J. (2011). Szkoła w epoce płynnej nowoczesności. W: J. Morbitzer. E. Musiał. I. Pulak (red.). Człowiek - Media - Edukacja (s. 219-225). Kraków: Wyd. UP. Nosal, C. (2011/2012). Złudzenia poznawcze wywoływane przez stare i nowe technologie informacyjne. Neodidagmata, 33/34, 77-79.

Okoń, W. (1998). Wprowadzenie do dydaktyki ogólnej. Warszawa: Żak.

Pachociński, R. (2002). Technologia a oświata. Warszawa: Wyd. IBE.

Pająk, A. (2013). E Ink czy LCD: który jest lepszy?, 3, Chip, dostępne na: https:// www.chip.pl/2013/03/e-ink-czy-lcd-ktory-jest-lepszy/?utm_source=chip\&utm_ medium=XML\&utm_campaign=partnerzy [dostęp: 6.12.2020].

Piecuch, A. (2008). Edukacja informatyczna na początku trzeciego tysiąclecia. Rzeszów: WO Fosze.

Piecuch, A. (2014a). Informacja i wiedza w edukacji. W: A. Jastriebow. K. Worwa (red.). Wspótczesne technologie informatyczne i ich zastosowanie w teorii i praktyce (s. 342-351). Radom: Wyd. UT-H.

Piecuch, A. (2014b). Uczeń w cyfrowej szkole. Nowe Horyzonty Edukacji, 1(8), 20-25. 
Piecuch, A. (2016). Nowe media - nowe problemy. Dydaktyka Informatyki, 11, 109-116.

Piecuch, A. (2019). Szkoła XXI wieku - problemy i wyzwania. Rzeszów: Wyd. UR.

Plewka, C. (2017). Technoedukacja to metoda czy cywilizacyjna konieczność? Problemy Profesjologii, 2, 24-25.

Polak, M. (2018). Konektywizm: połącz się, aby się uczyć. dostępne na: https://edunews.pl/badania-i-debaty/badania/1068-konektywizm-polacz-sie-aby-sie-uczyc [24.05.2018].

Prensky, M. (2001). Digital natives, digital immigrants. On the Horizon, MCB University Press, 9(5), 1-6.

Sawiński, J.P. (2018). Kluczowe kompetencje epoki cyfrowej. Dostępne na: https:// edunews.pl/badania-i-debaty/badania/1001-kluczowe-kompetencje-epoki-cyfrowej [dostęp: 23.05.2018].

Sawiński, J.P. (2018). Konektywizm, czyli rewolucja w uczeniu się? Dostępne na: https:// www.edunews.pl/badania-i-debaty/badania/1077-konektywizm-czyli-rewolucja-w-uczeniu-się [dostęp: 24.05.2018].

Siemieniecki, B. (2013). Pedagogika kognitywistyczna. Studium teoretyczne. Kraków: Impuls.

Small, G., Vorgan, G. (2011). iMózg. Jak przetrwać technologiczną przemianę współczesnej umysłowości. Poznań: Vesper.

Spitzer, M. (2012). Jak uczy się mózg. Warszawa: PWN.

Spitzer, M. (2015). Cyfrowa demencja. W jaki sposób pozbawiamy rozumu siebie i swoje dzieci. Słupsk: Dobra Literatura.

Tajemnica filtru światła niebieskiego - dostępne na: http://www.echirurgia.pl/zacma/ tajemnica_filtru_swiatla_niebieskiego.htm [dostęp: 24.05.2018].

Wieczorkowska-Wierzbińska, G. (2011). Psychologiczne ograniczenia. Warszawa: WN Wydziału Zarządzania UW.

Wróblewska, W. (2014). W kierunku dydaktyki epoki cyfrowej. Studia Dydaktyczne, 26, 196-206.

Zachrisson, B. (1970). Studia nad czytelnością druku. Warszawa: WNT.

\section{THE CONFUSED DIDACTICS OF NOWADAYS}

Abstract: Contemporary didactics is at a crossroads. On the one hand, it attempts to prevent
a decline of education's quality at all levels of education. On the other hand, it is searching for
methods of adaption to the present day and social expectations. The universal informatization
of schools was to become an antidote to the educational problems of the young generation.
Assumedly, IT resources, which is used during classes, should improve the quality of education, 
modernize and make the educational process more attractive, using the natural fascination of the young generation with new technologies. Following the universal informatization, a number of local and national projects (e.g. Digital School) were started based on IT resources. The results of national and foreign research into the effectiveness of IT-supported education clearly show that the solutions adopted are not effective. Synchronized with the practical activities undertaken in schools, new concepts also appeared: cognitivism and connectivism. They were to cause changes in the approach to learning and teaching processes, in order to ultimately positively affect the effectiveness of education. Indeed, are they able to change the image of education to the expected one, or do they perpetuate the existing state of affairs? In view of many emerging doubts, it is legitimate to ask: about the directions of further development of the IT-supported methodology, about the impact of new concepts on the quality of education. In this study, I try to argue with the mentioned problems.

Keywords: didactics, cognitivism, connectivism 